\title{
Theory and Empirics of Economic Inequality Influencing Economic Growth: A Study of Major Indian States
}

\author{
Debnarayan Sarker $^{1} \&$ Debraj Das ${ }^{1}$ \\ ${ }^{1}$ Centre for Economic Studies, Presidency University, Kolkata, India \\ Correspondence: Debraj Das, Research Scholar, Centre for Economic Studies, Presidency University, Kolkata, \\ India. E-mail: debraj.das84@gmail.com
}

\author{
Received: April 11, $2012 \quad$ Accepted: May 10, $2012 \quad$ Online Published: July 10, 2012 \\ doi:10.5539/ibr.v5n8p132 URL: http://dx.doi.org/10.5539/ibr.v5n8p132
}

\begin{abstract}
Unlike the conventional approach, this paper theoretically shows that when median voter's income is much below the mean level, higher inequality of income increases redistribution in favor of median voter, and thereby influencing higher economic growth provided that major share of tax-financed capital is allocated in public education which benefits all. In the empirical findings this study suggests that despite continuous increase in consumption inequality in major Indian states, redistribution in real social expenditure by Centre and States continues to increase in real per capita terms including median voter during post-reform period. Although inequality of consumption expenditure induces an increase in economic growth for about 50 per cent of major Indian states and the regression coefficients are almost insignificant, such tax-financed public education might act as externality to everybody if major tax financed resources are allocated on education. This might lead to a positive and significant impact into the growth process provided that the large proportion of working population of major Indian states get employment in the service sector. However the empirics of Indian states during the current years also show that service sector of Indian economy, which depends completely on stepping up of educational level to the working population, acts as the major contributor to growth.
\end{abstract}

Keywords: redistribution of income, median voter model, economic growth, consumption inequality, tax-financed public education, externality

JEL Classification: D90, E61, H23, H53, 015

\section{Introduction}

How is the nature of the redistribution programme related to the characteristics of the electorate? The basic political economy model seems to suggest that on the basis of individual optimization of the median voter preference each median individual determines his preferred fiscal policy. The overwhelming focus of the literature on the political economy of growth is the effect of income inequality on growth via the implied pressure for redistribution.

In democratic regime the basic political linkage is an application of the median voter model to choose the tax-based redistribution schemes, where an increase in inequality induces a fall in the position of the median voter relative to the mean. Then one of the most fundamental issues is the effect of greater inequality on redistribution when tax transfer programmes are chosen via political process in the democratic regime. The literature of political economy in the median voter model (Meltzer \& Richard, 1981; Persson \&Tabellini, 1991) suggests two general implications in this regard. (i) If the median voter's income is above the mean, there will be no program of redistribution, no matter how unequal the income distribution. Changes in income distribution will have no effect on the amount of redistribution if the changes do not reduce the median income below the mean. The median individual whose pre-tax income is equal or above the mean income will prefer zero tax rate and no lump-sum redistribution. (ii) On the other hand, if the median voter's income is below the mean, he will choose a positive tax-transfer programme, and a change in the redistribution of income which lowers the median relative to the mean (which may be thought of an increase in income inequality) will result in a higher tax rate and greater redistribution.

Why is redistribution issue of the median voter preference more important in a developing country like India, where all affected individuals are included in the democratic decision-making process? The recent report of $66^{\text {th }}$ 
round NSSO survey during 2009-10 (Government of India, 2011) which is based on Suresh Tendulkar's methodology (modified mixed reference period, MMRP) clearly reveals that $50 \%$ of rural Indian population have average monthly per capita expenditure (MPCE) of Rs 848.07, whereas the mean monthly per capita expenditure (MPCE) of all rural Indian population is Rs 1053.64. Similarly 50\% of urban Indian population have average monthly per capita expenditure (MPCE) of Rs 1397.99, whereas the mean monthly per capta expenditure (MPCE) of all urban Indian population is Rs 1984.46 (NSS $66^{\text {th }}$ round, 2009-10: Table T3 p.11). However the very recent data clearly shows that that the median voter in India has much lower income (expenditure) than the mean income (expenditure) in both rural and urban areas. Also important is that the extent of poverty of median voter of Indian population might come out from the NCEUS (2007) report. National Commission for Enterprises in the Unorganized Sector (2007) categorizes the population of the country with six groups. Extremely poor, who constitute 6.4 percent of total population, are those with a per capita per day (pcpd) consumption expenditure three-fourths of the official poverty line (an average of Rs. 8.9 per capita per day) of 2004-05. The second group, poor, who constitute 15.4 percent of the total population, were those between the extremely poor and up to official poverty line (average expenditure of Rs. $11.6 \mathrm{pcpd}$ ). The third group, marginally poor, who constitute 19 percent of total population, are with the per capita consumption expenditure of only 1.25 times the poverty line (i.e. Rs. $14.6 \mathrm{pcpd}$ ) and the fourth is called as vulnerable poor constitute about 36.2 percent of total population, have a per capita consumption expenditure of only two times the poverty line (Rs.20.3 p.c.p.d.). NCEUS total accounts of those four groups of poor, with an income of roughly between $\$ 2$ PPP (or below Rs.20.4 pcpd), works out to 77 per cent of the total population. These facts, however, clearly demonstrates that that the median voter in India is the poor, who have much lower income than the mean income of Indian population reflecting greater inequality of income for the median voter, the poor, relative to the mean.

The central issue of this paper is: how does the income inequality of median income in Indian states, where median voter in India, the poor, have much lower income than the mean income of Indian population, effect on economic growth via the implied pressure for redistribution? As mentioned earlier, the literature of political economy in the median voter model suggests that If the median voter's income is below the mean, he will choose a positive tax-transfer programme, and a change in the redistribution of income which lowers the median relative to the mean (which may be thought of an increase in income inequality) will result in a higher tax rate and greater redistribution. But the effect on growth of such greater redistribution has the following important implications:

(1) The basic political economy model of growth that clearly delivers a central result of this literature is that higher inequity of median voter's income (or much lower income of median voter than mean level) increases the pressure for redistribution even if is distortionary, which in turn leads to higher capital taxation and lower growth (Meltzer \& Richard, 1981; Persson \& Tabellini, 1991).

(2) In the world of capital market imperfection having higher inequality of median voter's income, it is no longer the case that higher capital taxation reduces growth. Redistribution effected through tax system will dampen the incentive to accumulate capital, but also ease credit constraints, thereby enhancing capital accumulation and growth (Galor \& Zeira, 1993; Banerjee \& Newman, 1993; Aghion \& Bolton, 1997).

(3) Tax-financed redistribution may also enhance growth in the case of externalities in the process of human capital accumulation in the presence of capital market imperfection, with non-distortionary nature of taxes (Saint-Paul \& Verdier, 1993).

Hence one of fundamental issues seem to be relevant in the context of developing country is whether redistribution may increase growth if the instruments of redistribution are distortionary even without the presence of capital market imperfections. Remaining the basic structure of Persson and Tabellini's linear model (1994) constant we have also tried to explore both theoretically and empirically that in a democratic regime like India higher inequality of median voter's income (or much lower the median income below the mean) increases the pressure for redistribution (even if it's distortionary) which in turn may lead to higher capital taxation and higher growth. In the theoretical model our fundamental hypothesis is that if the major part of linear tax on capital (tax financed public education) is introduced as positive externality into growth process as an extra unit of income devoted to public education which benefits all individuals (under the provision that each individual is supplied with the tax-financed public education with the same amount, rather than any inherent public good nature of public education), then the positive tax-transfer program of median voter, whose income is below the mean, may imply higher capital accumulation and higher growth.

The paper is organized as follows. Section 2 presents the theoretical underpinnings of fiscal model of redistribution and growth. First, the basic structure of Persson and Tabellini's linear model (1994) - where 
tax-transfer policies associated with income distribution tend to be distortionary, individuals face perfect credit market, individuals face constant returns to scale - have been primarily considered. Second, remaining the basic structure of Persson and Tabellini's linear model (1994) constant, we have also tried to explore that, unlike the Persson and Tabellini's linear model (1994), the income inequality may increase growth via the implied pressure for redistribution. Section 3 tries to explore the empirical justification of our theoretical explanation. Section 4 concludes.

\section{Redistribution Oriented Fiscal Policies}

\subsection{Persson and Tabellini's Linear Model}

First we present the basic structure of Persson and Tabellini's linear model (1994), which focuses the effect of income inequality on growth via the implied pressure for redistribution favored by the median voter in a democratic regime under the dynamic implication of redistributive programs. The model is one of overlapping generations. The assumptions of the model are as follows:

1) The economy is composed of two non-altruistic generations assumed of equal size, where the young supply one unit of labor inelastically and hold no capital, while the old only hold capital without supplying any labor and consume all their income with no bequests across generations.

2) The production structure is linear implying not only that pre-tax factor returns are independent of factor supplies, but also that the returns to labour, but not the returns to capital, is affected by an externality to capital accumulation.

3) Utility is homothetic function only of one's own consumption; where homotheticity is assumed for tractability.

4) There is a linear tax on capital, with the returns distributed lump-sum to the old.

5) Only the young vote at the rate at which capital will be taxed in the second period.

6) Factors are paid their marginal products, net of taxes and transfers.

7) Though variables in the model are taken as functions of calendar time, the growth is constant over the time period because of the stationarity of all the relevant parameters.

The aggregate production function in per capita term is

$$
Y_{t}=w_{t}+R_{t}
$$

so that the pre-tax return on capital is a constant $\mathrm{R}$, is dependent on capital labor ratio $\mathrm{k}_{\mathrm{t}}$.

The average wage rate $\mathrm{w}_{\mathrm{t}}$ depends on the economy wide stock of capital $\mathrm{k}_{\mathrm{t}}$ (determined in the previous period). Individual wages differ according to an individual specific skill component $\xi^{i}$. Assume that $\xi^{i}$ has zero mean and a non-positive median and is distributed in the population according to the known distribution $\mathrm{F}(\xi)$ independent of $\mathrm{k}_{\mathrm{t}}$.

Hence, the individual specific wage rate at $t, w_{t}{ }^{i}$, may be written:

$$
\mathrm{w}_{\mathrm{t}}^{\mathrm{i}}=\left(\mathrm{w}+\xi^{\mathrm{i}}\right) \mathrm{k}_{\mathrm{t}}
$$

So that the economy wide average wage rate is simply:

$$
\mathrm{w}_{\mathrm{t}}=\mathrm{w} \mathrm{k}_{\mathrm{t}}
$$

The common problem of the young is the standard problem in the two period overlapping generations (OLG) model, namely how much to save, given expected returns in the following period. There is a linear tax on capital (tax rate $\tau$ on capital) with the returns distributed lump-sum to the old. The economic problem of the young consumer voter $\mathrm{i}$ can be represented as choosing first and second period consumption $\mathrm{C}_{1}{ }^{\mathrm{i}}$ and $\mathrm{C}_{2}{ }^{\mathrm{i}}$ to maximize.

$$
\Omega^{\mathrm{i}}=\mathrm{u}\left(\mathrm{C}_{1}^{\mathrm{i}}, \mathrm{C}_{2}{ }^{\mathrm{i}}\right)
$$

Subject to the budget constraint in the two periods:

$$
\mathrm{C}_{1}{ }^{\mathrm{i}}+\mathrm{k}_{2}{ }^{\mathrm{i}}=\mathrm{w}_{1}{ }^{\mathrm{i}}
$$

Where $\mathrm{K}_{2}{ }^{\mathrm{i}}$ is saving to be carried over to the next period, and

$$
\mathrm{C}_{2}{ }^{\mathrm{i}}=(1-\tau) \mathrm{Rk}_{2}{ }^{\mathrm{i}}+\mathrm{v}
$$

Where $\mathrm{v}$ is the lump-sum transfer.

Maximization of (3) subject to (4) and (5) yields a first-order condition of the form

$$
\mathrm{u}_{1}\left(\mathrm{C}_{1}{ }^{\mathrm{i}}, \mathrm{C}_{2}{ }^{\mathrm{i}}\right) / \mathrm{u}_{2}\left(\mathrm{C}_{1}{ }^{\mathrm{i}}, \mathrm{C}_{2}{ }^{\mathrm{i}}\right)=(1-\tau) \mathrm{R}
$$


Where $\mathrm{U}_{1}$, for example, represents the derivation of a(.,.) with respect to first argument.

With homothetic preferences, (where demand rises proportionally with income), one can go further, since the ratio of consumption in the two periods is independent of income and depends only on the inter-temporal price $(1-\tau) \mathrm{R}$. Since individuals differ only in their level of wage income, we may write their relation as

$$
\mathrm{C}_{1}{ }^{\mathrm{i}} / \mathrm{C}_{2}{ }^{\mathrm{i}}=\Phi[(1-\tau) \mathrm{R}]
$$

Where $\Phi^{\prime}()>$.0 .

Substituting (4) into (5) and using (6a) to solve for consumption, one obtains

$$
\begin{aligned}
\mathrm{C}_{1}{ }^{\mathrm{i}} & =\frac{(1-\tau) R \mathrm{w}_{1}^{\mathrm{i}}+\mathrm{v}}{\Phi[(1-\tau) \mathrm{R}]+(1-\tau) \mathrm{R}} \\
\mathrm{C}_{2}{ }^{\mathrm{i}} & =\Phi[(1-\tau) \mathrm{R}] \mathrm{C}_{1}{ }^{\mathrm{i}} \\
\mathrm{K}_{2}{ }^{\mathrm{i}} & =\frac{\Phi \mathrm{w}_{1}^{\mathrm{i}}-\mathrm{v}}{\Phi[(1-\tau) \mathrm{R}]+(1-\mathrm{T}) \mathrm{R}}
\end{aligned}
$$

Given (2), (7) makes clear how the distribution of skills $\mathrm{F}(\mathrm{C})$ induces a distribution asset holding $\mathrm{K}_{2}{ }^{\mathrm{i}}$, with more skilled (and hence higher income) individuals accumulating more capital.

We now derive the economy's growth rate and show how it depends on the rate of capital taxation $\tau$. From (1) and the version of (2), it is clear that output $y_{t}$ grows at the same rate of $K_{t}\left(y_{t}=w K_{t}+R K_{t}\right)$.

To derive the growth rate of capital, one must first clear that the model with the government budget constraint connecting taxes and transfers namely:

$$
\tau \mathrm{R} \mathrm{K}_{2}=\mathrm{v}
$$

where $\mathrm{K}_{2}$ is the average level of saving that is, capital accumulation in the economy.

Substituting (8) into the economy wide aggregate analogue of (5), one sees that consumption will also grow at the same rate in an equilibrium.

Using the economy wide analogues of (4) and (2) to write

$$
\mathrm{K}_{2}=\sum \mathrm{w}_{1}{ }^{\mathrm{i}}-\sum \mathrm{C}_{1}{ }^{\mathrm{i}}=\mathrm{wK}_{1}-\sum_{\mathrm{i}} \mathrm{C}_{1}{ }^{\mathrm{i}}
$$

Again using (7) and (8) for $\mathrm{C}_{1}{ }^{\mathrm{i}}$, we may write (after some algebra) the growth rate:

$$
\hat{y}(\tau, \mathrm{w}, \mathrm{R})=\frac{K_{2}}{K_{1}}-1=\frac{\mathrm{w} \Phi[(1-\tau) \mathrm{R}]}{\Phi[(1-\tau) \mathrm{R}]+\mathrm{R}}-1
$$

One then immediately derives that $\partial \hat{y} / \partial \tau=-\left[\mathrm{w} R^{2} \Phi^{\prime} /(\Phi+\mathrm{R})^{2}\right]<0$.

Hence, an increase in the tax rate on capital discourages capital accumulation and hence lowers growth.

Now using (2), (7) and (9), one may have

$$
\mathrm{K}_{2}^{\mathrm{i}}-\mathrm{K}_{2}=\frac{\Phi[(1-\tau) \mathrm{R}] \mathrm{K}_{1}}{\Phi[(1-\tau) \mathrm{R}]+(1-\tau) \mathrm{R}} \mathrm{C}^{\mathrm{i}}
$$

So that individual's tax preferences depend on their skill endowment relative to mean, with it being possible to rank their preferences for redistribution by their skill endowment. This reflects the structure of the redistribution program, with an individual. Paying taxes according his capital holding $\mathrm{K}_{2}{ }^{\mathrm{i}}$ and receiving transfers in return is determined by the economy wide average $\mathrm{K}_{2}$.

Since individual preferences over taxes are single peaked for each voter, Persson and Tabellini use the Median Voter Theorem to derive the political equilibrium policy as that favored by the median voter. Given the discussion immediately following (10), this is the voter with the median skill endowment, which we denote $\epsilon^{\text {med }}$.

(10) represents the benefit of redistribution for the median voter, because it is the difference between an individual paying taxes according o his capital holding minus(-) receiving transfers in return as determined by the economy wide average capital accumulation.

What is the impact on median income on the benefits of redistribution for median voter via the implied pressure of equilibrium tax rate on capital? The important implications are:

a) If the median voter has the mean skill level (i.e. $\epsilon^{\text {med }}=0$ ), he strictly prefers zero tax, because of the distortionary nature of taxation.

b) If the income distribution is skewed to the right, meaning that the median income is below the mean level, the equilibrium tax rate on capital will be positive. 
What is the effect of income inequality on growth via the implied pressure for redistribution if median voter's income is equal to mean or greater than mean or less than mean?

The implications are as follows:

a) If the median voter's income is above the mean and the tax rates on capital are constrained to be non-negative, there will be no program of redistribution, no matter how unequal is the income distribution, because in such a case the equilibrium tax rate on capital will be negative via (10) i.e. there will be negative tax-transfer problem. $\left[\mathrm{W}_{1}{ }^{\mathrm{i}}>\mathrm{W}_{1}\right]$

b) Changes in the income distribution will have no effect on the amount of redistribution if the changes does not reduce the median income below the mean. It implies that if the median voter's income is equal the mean or above the mean, changes in the income redistribution will have no effect on the amount of redistribution.

c) If and only if the median voter's income is below the mean, he will choose a positive tax-transfer program and a change in the distribution of income which lowers the median relative to mean (which can be thought of as an increase in income inequality) will result in a higher $\tau$. This will imply lower capital taxation via (7), and hence from (10) lowers growth. The central result is: higher inequality increases the pressure of redistribution, which in turn leads to higher capital taxation and lower growth. It is worth mentioning that these results hold true if we consider a non-linear model with constant returns to scale in the presence of capital market imperfections (Drazen, 2000: 474-477).

\subsection{Our Theoretical Underpinnings}

Now we try to examine that remaining the basic structure of Persson and Tabellini's linear model constant, if the major part of linear tax on capital (tax financed public education) is introduced as positive externality into growth process, as an extra unit of income devoted to public education which benefits all individuals (under the provision that each individual is supplied with the tax-financed public education with the same amount, rather than any inherent public good nature of public education), then the positive tax-transfer program of median voter, whose income is below the mean, may imply higher capital accumulation and higher growth. In this model the extra assumptions incorporated in Persson and Tabellini model is: (8) each individual is supplied with the tax-financed public education with the same amount rather than any inherent public good nature of public education, because both young and old vote for such a provision. Then the linear tax on capital is of two types: the returns of one part $(1-\lambda)$ is distributed lump-sum to the old and the other part $(\lambda)$, tax-financed public education which acts as externality to everybody. (9) the share of tax-financed capital which introduces a positive externality into the growth process through public education is greater than share of capital which distributed lump-sum to the old.

Hence the budget constraints in the two periods [equations (4) and (5)] are as follows:

$$
\begin{aligned}
& \mathrm{C}_{1}{ }^{\mathrm{i}}+\mathrm{k}_{2}{ }^{\mathrm{i}}+\lambda \mathrm{R} \tau \mathrm{K}_{2}{ }^{\mathrm{i}}=\mathrm{w}_{1}{ }^{\mathrm{i}} \\
\mathrm{C}_{2}{ }^{\mathrm{i}} & =\mathrm{R} \mathrm{K}_{2}{ }^{\mathrm{i}}-\left\{(1-\lambda) \mathrm{R} \tau \mathrm{K}_{2}{ }^{\mathrm{i}}+\lambda \mathrm{R} \tau \mathrm{K}_{2}{ }^{\mathrm{i}}\right\}+(1-\lambda) \mathrm{R} \mathrm{K}_{2}{ }^{\mathrm{i}} \\
& =\mathrm{R} \mathrm{K}_{2}{ }^{\mathrm{i}}-\lambda \mathrm{R} \tau \mathrm{K}_{2}{ }^{\mathrm{i}} \\
& =(1-\lambda \tau) \mathrm{R} \mathrm{K}_{2}{ }^{\mathrm{i}}
\end{aligned}
$$

where $(1-\lambda) \mathrm{R} \tau \mathrm{K}_{2}{ }^{\mathrm{i}}$ is a lump-sum transfer.

It is assumed that the share of tax-financed capital which introduces a positive externality into the growth process through public education is greater than share of capital which distributed lump-sum to the old [i.e. $\lambda>(1-\lambda)$ ]

The equation (6), (maximization of (3), subject to (4) and (12)) yields a first-order condition of the form:

$$
\frac{\mathrm{U}_{1}\left(\mathrm{C}_{1}^{\mathrm{i}}, \mathrm{C}_{2}^{\mathrm{i}}\right)}{\mathrm{U}_{2}\left(\mathrm{C}_{1}^{\mathrm{i}}, \mathrm{C}_{2}^{\mathrm{i}}\right)}=(1-\lambda \tau) \mathrm{R} /(1+\lambda \mathrm{R} \tau)
$$

Then we may write equation (6a) as

$$
\frac{\mathrm{C}_{2}^{\mathrm{i}}}{\mathrm{C}_{1}^{\mathrm{i}}}=\Phi[(1-\lambda \tau) \mathrm{R} /(1+\lambda \mathrm{R} \tau)]
$$

Where $\Phi^{\prime}()>$.0 . Substituting (4) into (12) and using (14) to solve for consumption, one obtains

$$
\begin{gathered}
\left.\mathrm{C}_{1}{ }^{\mathrm{i}}=\left\{(1-\lambda \tau) \mathrm{R} \mathrm{w}_{1}\right\} / \Phi[(1-\lambda \tau) \mathrm{R} /(1+\lambda \mathrm{R} \tau)](1+\lambda \mathrm{R} \tau)\right]+\{(1-\lambda \tau) \mathrm{R} \\
\mathrm{C}_{2}^{\mathrm{i}}=\Phi[(1-\lambda \tau) \mathrm{R} /(1+\lambda \mathrm{R} \tau)] \mathrm{C}_{1}{ }^{\mathrm{i}} \\
\mathrm{K}_{2}{ }^{\mathrm{i}}=\frac{\Phi\left(\left[\left[\frac{(1-\lambda \tau) \mathrm{R}}{1+\lambda \mathrm{R}}\right]\{(1+\lambda \tau \mathrm{R})+(1-\lambda \tau) \mathrm{R}\}-(1-\lambda \tau) \mathrm{R}\right) \mathrm{w}_{1}^{\mathrm{i}}\right.}{\Phi\left(\left[\frac{(1-\lambda \tau) \mathrm{R}}{1+\lambda \tau \mathrm{R}}\right]\{(1+\lambda \tau \mathrm{R})+(1-\lambda \tau) \mathrm{R}\}(1+\lambda \mathrm{R} \tau)\right)}
\end{gathered}
$$


Here also given (2), (15) makes clear how the distribution of skills $F(€)$ induces a distribution of asset holding $\mathrm{K}_{2}{ }^{\mathrm{i}}$, with more skilled (and hence higher income) individuals accumulating more capital.

Then government budget constraint connecting taxes and transfers may be written as

$$
(1-\lambda) K_{2} R \tau+\lambda K_{2} R \tau=K_{2} R \tau
$$

We may write (after some algebra) the growth rate $\hat{y}$ as

$$
\begin{aligned}
& \hat{y}(\tau, \mathrm{w}, \mathrm{R})=\frac{K_{2}}{K_{1}}-1 \\
& =\frac{\Phi\left(\left[\left[\frac{(1-\lambda \tau) \mathrm{R}}{1+\lambda \tau \mathrm{R}}\right]\{(1+\lambda \tau \mathrm{R})+(1-\lambda \tau) \mathrm{R}\}-(1-\lambda \tau) \mathrm{R}\right) \mathrm{w}_{1}^{\mathrm{i}}\right.}{\Phi\left(\left[\frac{(1-\lambda \tau) \mathrm{R}}{1+\lambda \tau \mathrm{R}}\right]\{(1+\lambda \tau \mathrm{R})+(1-\lambda \tau) \mathrm{R}\}(1+\lambda \mathrm{R} \tau)\right)}-1 \\
& \partial \hat{y} / \partial \tau \\
& / \partial 0
\end{aligned}
$$

Then an increase in tax rate on capital may encourage capital accumulation and hence increases growth. It implies that if the share of tax-financed capital which introduces a positive externality into the growth process through public education is greater than share of capital which distributed lump-sum to the old, then an increase in the tax rate on capital may encourage capital accumulation and hence increasers growth.

Then the benefit of redistribution for the median voter following Persson and Tabellini's median voter theorem), who derive the political equilibrium policy as that favoured by the median voter may be written as

$$
\begin{aligned}
\mathrm{K}_{2}{ }^{\mathrm{i}}-\mathrm{K}_{2} & =K_{1} \frac{\Phi\left(\left[\left[\frac{(1-\lambda \tau) \mathrm{R}}{1+\lambda \tau \mathrm{R}}\right]\{(1+\lambda \tau \mathrm{R})+(1-\lambda \tau) \mathrm{R}\}-(1-\lambda \tau) \mathrm{R}\right) \epsilon_{1}^{\mathrm{i}}\right.}{\Phi\left(\left[\frac{(1-\lambda \tau) \mathrm{R}}{1+\lambda \tau \mathrm{R}}\right]\{(1+\lambda \tau \mathrm{R})+(1-\lambda \tau) \mathrm{R}\}(1+\lambda \mathrm{R} \tau)\right)} \\
& =K_{1} \frac{\Phi\left(\left[\left[\frac{(1-\lambda \tau) \mathrm{R}}{1+\lambda \tau \mathrm{R}}\right]\{(1+\lambda \tau \mathrm{R})+(1-\lambda \tau) \mathrm{R}\}-(1-\lambda \tau) \mathrm{R}\right){ }_{1}^{\mathrm{i}}\right.}{\Phi\left(\left[\frac{(1-\lambda \tau) \mathrm{R}}{1+\lambda \tau \mathrm{R}}\right]\{(1+\lambda \tau \mathrm{R})+(1-\lambda \tau) \mathrm{R}\}(1+\lambda \mathrm{R} \tau)\right)} \epsilon^{\mathrm{med}}
\end{aligned}
$$

What is the effect of income inequality on growth via the implied pressure of redistribution of the median voter's income is equal to /less than /greater than mean? The implications are

1) Changes in the income distribution will have no effect if the changes between median income and mean income are zero.

2) If the median voter's income is below the mean and the tax rates on capital are constrained to be non-negative, there may be program for redistribution if share of tax-financed capital is greater than share of capital which distributed lump-sum to the old, no matter how unequal the income distribution. This may imply higher capital accumulation and via (17) increases growth.

Our theoretical underpinnings seem to suggests that, like Persson and Tabellini (1994), if the median voter's income is below the mean, he will choose a positive tax-transfer program and a change in the distribution of income which lowers the median relative to mean (which can be thought of as an increase in income inequality will result in a higher $\tau$. But unlike Persson and Tabellini, this will imply higher capital accumulation, and via (17) increases growth.

The central point of our theoretical model is: if the median voter's income is below the mean, it implies higher inequality of income which induces the median voter choose a positive tax-transfer program which in turn increases the pressure of redistribution in favor of the median voter influencing higher capital accumulation, and higher economic growth.

\section{Results and Discussion}

Based on the theoretical underpinnings, our central empirical issue seeks to examine whether inequality of income in major Indian states increases redistribution in favor of median voter, and thereby influencing higher economic growth. Before examining the central issue, it is pertinent to examine as to how far median voter's income/consumption is below the mean level in all major Indian states appearing from the latest data, and whether inequality of income (expenditure) increase for over past 30 years period in all major Indian states.

\subsection{Median and Mean Consumption Expenditure}

The latest National Sample Survey Organisation (NSSO) data (66th round quinquennial survey, 2009-10) in India based on household consumer expenditure of Monthly Per Capita Expenditure (MPCE) for Modified Mixed Reference Period' (MMRP) (Note 1) shows that both median level of rural MPCE and urban MPCE (in Rs.) are much below their respective mean level (Table 1). In rural India, while average rural MPCE was Rs.1054, the 
median level of rural MPCE was Rs.895 - half the rural population belonged to households with MPCE below this level. In urban India, where average MPCE was Rs.1984, the median level of MPCE wasRs.1502 - half the urban population had MPCE below this level. State-wise, the latest NSS data also show that MPCE (in Rs.) of the $5^{\text {th }}$ decile of both rural and urban population is much below the mean in all major Indian states indicating that the median voter's expenditure happens to be much below the mean for both urban and rural population in all major Indian states.

Table 1. Fifth deciles of distribution and average MPCE (MMRP) in the rural and urban areas (in Rs.): Major Indian States and all-India (2009-10)

\begin{tabular}{lllll}
\hline Major Indian & $5^{\text {th }}$ decile of rural & $\begin{array}{l}\text { Average rural } \\
\text { population }\end{array}$ & $\begin{array}{l}5^{\text {th }} \text { decile of urban } \\
\text { population }\end{array}$ & $\begin{array}{l}\text { Average urban } \\
\text { population }\end{array}$ \\
\hline States & 1058 & 1233.76 & 1652 & 2237.60 \\
Bihar & 709 & 780.15 & 943 & 1237.54 \\
Chhattisgarh & 706 & 783.57 & 1397 & 1647.32 \\
Gujarat & 971 & 1109.76 & 1604 & 1909.06 \\
Haryana & 1270 & 1509.91 & 1926 & 2321.49 \\
Jharkhand & 702 & 825.15 & 1230 & 1583.75 \\
Karnataka & 878 & 1020.40 & 1690 & 2053.24 \\
Kerala & 1451 & 1835.22 & 1751 & 2412.58 \\
Madhya Pradesh & 762 & 902.82 & 1238 & 1665.77 \\
Maharashtra & 1045 & 1152.79 & 1778 & 2436.75 \\
Orissa & 716 & 818.47 & 1173 & 1548.36 \\
Punjab & 1365 & 1648.92 & 1695 & 2108.79 \\
Rajasthan & 1003 & 1179.40 & 1359 & 1663.08 \\
Tamil Nadu & 1002 & 1159.69 & 1540 & 1947.61 \\
Uttar Pradesh & 795 & 899.10 & 1127 & 1573.91 \\
West Bengal & 867 & 952.32 & 1435 & 1964.78 \\
all-India & $\mathbf{8 9 5}$ & $\mathbf{1 0 5 3 . 6 4}$ & $\mathbf{1 5 0 2}$ & $\mathbf{1 9 8 4 . 4 6}$ \\
\hline
\end{tabular}

\subsection{Inequality in Consumption Expenditure}

A close examination of the values of the Gini Coefficients of MPCE for the first quinquennial NSS round (1972-73) and seventh quinquennial NSS round (2004-05) for the rural and urban sectors of 15 major states (Note 2) (Table 2) reveals as follows: (a) In the rural areas, the inequality has declined in 8 states out of 15 (53 per cent cases) during 1973 - 2005, whereas it has increased in other states. Maximum decline in the values of Gini coefficient has been observed for the state of Bihar followed by Rajasthan. Other States that have registered a decline in Gini coefficient are Gujarat, Karnataka, Madhya Pradesh, Orissa, Punjab and West Bengal. The states where the Gini Coefficients have increased most are Punjab, Andhra Pradesh, Gujarat and Uttar Pradesh. (b) In the urban areas, consumption inequality (Gini Coefficient) has not declined in any state during 1973-2005; rather Urban Gini increases in all major Indian states over time. The states where the Gini Coefficient have increased most are Punjab, Andhra Pradesh, Gujarat and Uttar Pradesh. This indicates that the gap between rich and poor is increasing in urban areas.

Thus the values of the Gini Coefficient of MPCE show that in the urban areas, the inequality (Gini Coefficient) has not declined in any state during 1973-2005, whereas in the rural areas, the inequality has declined in 8 states during 1973 - 2005 indicating that the gap between the rich and the poor is more increasing in urban areas as compared with urban areas among major Indian states. However the overall findings suggest that median voter's consumption expenditure is much below the mean in all major Indian states (Table 1) and inequality of income (expenditure) for over past 30 years period has increased in all major Indian states (Table 2). Hence the corresponding issue usually comes up as to whether inequality of income in major Indian states increases redistribution in favor of median voter. First, we examine the issue in respect of the performance of financial redistribution. 
Table 2. Gini Coefficient for Monthly Per Capita Consumer Expenditure (in Rs.): Major Indian States and all-India (1972-73 to 2004-05)

\begin{tabular}{|c|c|c|c|c|}
\hline Major Indian States & $\begin{array}{l}\text { 1972-73 } \\
\text { (Rural) }\end{array}$ & $\begin{array}{l}\text { 2004-05 } \\
\text { (Rural) }\end{array}$ & $\begin{array}{l}1972-73 \\
\text { (Urban) }\end{array}$ & $\begin{array}{l}\text { 2004-05 } \\
\text { (Urban) }\end{array}$ \\
\hline Andhra Pradesh & 0.273 & 0.288 & 0.297 & 0.370 \\
\hline Bihar & 0.288 & 0.208 & 0.323 & 0.330 \\
\hline Gujarat & 0.302 & 0.268 & 0.242 & 0.304 \\
\hline Haryana & 0.277 & 0.323 & 0.315 & 0.361 \\
\hline Karnataka & 0.273 & 0.264 & 0.323 & 0.365 \\
\hline Kerala & 0.310 & 0.341 & 0.390 & 0.400 \\
\hline Madhya Pradesh & 0.306 & 0.269 & 0.348 & 0.393 \\
\hline Maharashtra & 0.310 & 0.258 & 0.367 & 0.371 \\
\hline Orissa & 0.312 & 0.282 & 0.347 & 0.348 \\
\hline Punjab & 0.307 & 0.278 & 0.313 & 0.393 \\
\hline Rajasthan & 0.316 & 0.248 & 0.333 & 0.367 \\
\hline Tamil Nadu & 0.272 & 0.315 & 0.315 & 0.358 \\
\hline Uttar Pradesh & 0.277 & 0.287 & 0.312 & 0.370 \\
\hline West Bengal & 0.305 & 0.273 & 0.338 & 0.376 \\
\hline all-India & 0.302 & 0.297 & 0.341 & 0.343 \\
\hline
\end{tabular}

\subsection{Performance of Financial Redistribution}

The head 'Social Services' includes, among others, education, health and family welfare, water supply, and sanitation. The expenditures under anti-poverty programmes are also incorporated in social heads, although in budget expenditures in India as well as in Indian states all these expenditures are listed under the head 'Rural Development'. So, overall social expenditure by Centre and States combines both Social services and Rural Development under Social Sectors (Dev, 2007: 237). Also important is that both Centre and States do not demarcate expenditure on social services in rural and urban areas separately.

There are different ways of examining the trends of redistribution of social sector expenditure. One way is to look into social sector expenditures as a percentage of GDP in the case of Centre or GSDP (Gross State Domestic Product) in respect of States. A second way is to work out social sector expenditure as percentage of aggregate budget expenditure (in Rs.). The third way is to examine into the real per capita expenditure (at constant prices) for the social sector. Importantly, the third issue particularly shows the real picture of financial redistribution in favor of per capita Indian population including the median voter. However, we use all three approaches when we highlight social sector expenditure (aggregate social sector expenditure) in all India basis, but restrict the third approach in respect of separate study for all major Indian states. Table 3 portrays all these three approaches in all India basis during pre-and post-reform periods (for the period 1987-88 to 2010-11).

As a percentage of GDP, India spends around 6 to $8 \%$ on the social sector. Both in 1996-97 and in 2001-02 the share of GDP reaches at minimum $(6.30 \%)$ whereas it reaches at maximum in 2010-11 (7.67\%). The increase in 1998-99 and 1999-2000 may be partly due to an increase in the salaries as a result of the recommendations of the fifth pay-commission. The same story is repeated in recent years. No clear cut trend is discernable during 1987-2011.

As a percentage of aggregate expenditure, India spends between $24 \%$ and $30 \%$ on the social sector. The percentage started to increase in the middle of the 1990s. Since 1995-96 a higher percentage of government expenditure goes to the social sector than when the reforms started (1990-91) or during the last years preceding to reforms. Although there are some fluctuations in the middle years, India shows a mild increasing trend in her aggregate public expenditure on the social sector.

As regards real per capita social sector expenditure is concerned, per capita social sector expenditure (at constant prices), which shows particularly the real picture of financial redistribution in per capita terms including the median voter, by Centre and States has an increasing trend over 24 years (1987-2011). Per capita expenditure rises from Rs. 564 to 995 , an increase of $76.41 \%$ in 24 years.

In order to examine separately the trend of financial redistribution in per capita terms of social sector expenditure for major Indian states since 1980, compound growth rate was calculated (Note 3). The results (Table 4) show that redistribution in real per capita social expenditure continues to increase in respect of time during 1980-2010 
and the annual compound growth rates for all major Indian states are highly significant. However the overall findings lead to the fact that with the increase of consumption inequality (Table 3), there appears an increase in financial redistribution in favor of per capita terms including the median voter (Table 4).

Table 3. Social Sector Expenditure (Social Services and Rural Development) Expenditure (Revenue and Capital) by Centre and States (1987-2011)

\begin{tabular}{cccc}
\hline Year & As \% of GDP & As \% of Aggregate Public Expenditure & Per capita Expenditure (in Rs.) in 1993-04 prices \\
\hline $1987-88$ & 7.26 & 25.29 & 564 \\
$1988-89$ & 6.95 & 25.22 & 585 \\
$1989-90$ & 7.17 & 25.19 & 635 \\
$1990-91$ & 6.78 & 24.85 & 623 \\
$1991-92$ & 6.58 & 24.28 & 599 \\
$1992-93$ & 6.38 & 24.06 & 594 \\
$1993-94$ & 6.46 & 24.58 & 622 \\
$1994-95$ & 6.39 & 25.01 & 632 \\
$1995-96$ & 6.40 & 25.95 & 674 \\
$1996-97$ & 6.30 & 26.46 & 716 \\
$1997-98$ & 6.41 & 26.18 & 763 \\
$1998-99$ & 7.01 & 27.36 & 882 \\
$1999-00$ & 7.14 & 26.75 & 951 \\
$2000-01$ & 7.45 & 26.56 & 988 \\
$2001-02$ & 6.30 & 23.42 & 859 \\
$2002-03$ & 7.11 & 24.78 & 995 \\
$2003-04$ & 6.82 & 24.36 & 998 \\
$2004-05$ & 6.71 & 25.24 & 970 \\
$2005-06$ & 7.21 & 25.71 & 954 \\
$2006-07$ & 7.34 & 25.92 & 991 \\
$2007-08$ & 7.27 & 26.22 & 962 \\
$2008-09$ & 7.15 & 26.15 & 958 \\
$2009-10$ & 7.5 & 29.24 & 998 \\
$2010-11$ & 7.67 & 30.01 & 995 \\
\hline
\end{tabular}

Table 4. Compound Growth of Per Capita Social Expenditure for Major Indian States (81-2010)

\begin{tabular}{lll}
\hline States & Growth Rate & $\mathrm{R}^{2}$ \\
\hline A.P. & 1.13 & .92 \\
ASSAM & 1.12 & .96 \\
BIHAR & 1.1 & .94 \\
GUJARAT & 1.13 & .98 \\
HARYANA & 1.12 & .74 \\
KARNATAKA & 1.13 & .98 \\
KERALA & 1.18 & .98 \\
M.P. & 1.12 & .98 \\
MAHARASTRA & 1.13 & .98 \\
ORISSA & 1.11 & .97 \\
PUNJAB & 1.11 & .96 \\
RAJASTHAN & 1.14 & .98 \\
T.N. & 1.14 & .97 \\
U.P. & 1.12 & .96 \\
W.B. & 1.11 & .96 \\
\hline
\end{tabular}

\subsection{Performance of Physical Redistribution}

A lot has been achieved over the past half century in respect of physical development of social sector in India, despite the fact that there are inter-state (state-wise) as well inter-regional (rural-urban) variations in development. The literacy rate of India has increased from less than 20 per cent in 1951 to 64 per cent in 2001, to 74 per cent in 2011.74 in every 100 Indians can now read, write and understand written text in contrast to 20 
per cent in 1951 or to 64 in 2001. GEM (gross enrolment measures) - combined primary, secondary and tertiary school enrolment ratio - also substantially improved during over the said period in all India level. The health indicators show that life expectancy in India improved from around 37 per cent in 1951 to 65 in 2000. The infant mortality declined from 146 to 70 during the same period. Very recent Sample Registration System Data from the Registrar general of India (RGI), census office, places the IMR of the country for 2010 at 47 (Sinha, 2012: 16). It implies that IMR of the country has substantially increased for over last 60 years between 1951 and 2010.

Without demarcating rural-urban sectors and male-female gap, we attempt to examine the physical performance of some social indicators among major Indian states. As the inter-state data for most of the social components are presented sector-wise (rural-urban divide), as per availability of inter-state level data we examine the physical performance of four important social indicators (Note 4) - literacy (LIT), gross enrolment ratio(GER), infant mortality (IMR) and life expectancy at birth (LEB) - among major Indian states over the past thirty years based on the measurement of composite index (Note 5) (Table 5). The index ranges from 0 to 1 . For composite index, Kerala records the highest rank and registers the highest value (0.819) of all major Indian states followed by Tamil Nadu, Maharashtra, Karnataka, Gujarat, West Bengal, Punjab, Haryana, Andhra Pradesh, Assam, Rajasthan, Madhya Pradesh, Orissa, Bihar and Uttar Pradesh. For other major Indian states, the physical performance of both health and education is much weaker for Uttar Pradesh, Bihar, Orissa, Madhya Pradesh Rajasthan, and Assam compared with other major Indian states. Out of four important social indicators, although Kerala tops all for three components registering the highest value of indices (1), the index is much lower than most of the major Indian states for GER (0.28), which measures combined primary, secondary and tertiary school enrolment ratio. No doubt, despite the fact that Kerala has the highest literacy level of the country appearing from Census of India, 2011 (100 in every 100 people in Kerala can now read, write and understand written text), in respect of GER, Kerala's position is lower than 10 major Indian states out of 15. What it implies is that all students entering grade 1 are not all retained in educational institution for the subsequent period. So, retaining students in the educational institution has become more difficult task than enrolling them for Kerala in particular. For other states, literacy index is less than 0.5 for all except Maharashtra and Tamil Nadu; GER is less than 0.5 for 6 states namely Andhra Pradesh, Bihar, Haryana, Orissa, Punjab and Uttar Pradesh. So, literacy index is still much lower for majority of Indian states and enrolling is more difficult task than retaining the students in educational institution for most of major Indian states. For health indicators, the IMR index is more than 0.5 for about 50 per cent of major Indian states ( 7 out of 15), LEB index is more than 0.5 for four major Indian states. However, most of the major Indian states have registered poorer health performance than the rest.

Table 5. Index of Physical Performance of Health and Education for Major Indian States (1980-2010)

\begin{tabular}{llllll}
\hline States & LIT & LEB & GER & 1-IMR & COMB \\
\hline A.P. & .17 & .39 & .43 & .56 & .389 \\
ASSAM & .27 & .05 & .76 & .33 & .35 \\
BIHAR & .02 & .18 & .07 & .48 & .188 \\
GUJARAT & .48 & .35 & .81 & .45 & .524 \\
HARYANA & .38 & .51 & .22 & .47 & .396 \\
KARNATAKA & .38 & .48 & .68 & .59 & .531 \\
KERALA & 1.00 & 1.00 & .28 & 1.00 & .819 \\
M.P. & .21 & 0.00 & .84 & 0.00 & .262 \\
MAHARASTRA & .59 & .56 & .71 & .58 & .608 \\
ORISSA & .28 & .09 & .45 & .03 & .215 \\
PUNJAB & .43 & .70 & .15 & .51 & .448 \\
RAJASTHAN & .11 & .20 & .50 & .26 & .268 \\
T.N. & .53 & .45 & .89 & .67 & .634 \\
U.P. & .14 & .06 & .04 & .23 & .118 \\
W.B. & .42 & .42 & .59 & .64 & .51 \\
\hline
\end{tabular}

\subsection{Effect of Inequality on Growth}

An ordinary least square regression (OLS) linear model is used to examine the effect of consumption inequality on economic growth (NSDP growth in percentages) among major Indian states based on 25 year data on and from 1981 to 2005 (Note 6). The positive relationship is expected between consumption inequality and economic growth (NSDP growth in percentages). But the basic limitation of this regression model is that the data of the main independent variable (choice variable) of the regression equation, Gini coefficient, is separate for both rural 
and urban areas of every state, whereas the data of dependent variable- NSDP growth in percentage of major Indian states - is combined for all. So, both rural and urban consumption Gini coefficient of a state have been considered as the choice independent variables in examining the separate effect of both Rural and Urban Gini coefficient on the combined rural plus urban NSDP growth of the same state. However, among other limitations of this regression analysis, we do not get continuous yearly data for all the variables for our study, hence we have to use interpolation and extrapolation for obtaining the missing data for twenty five year data on and from 1981 to 2005 (Note 7).

The control variables in the regression equations are literacy rate (LIT), life expectancy at birth (LEB), infant mortality (IMR) and the growth of development expenditure (in percentages). The first three are physical social factors and the rest is financial social factor. The positive relationship is expected between LIT, LEB, the growth of development expenditure (in percentages) and NSDP growth (in percentages). Negative relationship is expected between IMR and NSDP growth (in percentages). We consider the development expenditure (instead of expenditure on social services) as one of the explanatory variables in regression equations because 'Social sector expenditure by Centre and States' combines expenditure on both Social Services and Rural Development (Table 3), whereas expenditure on Social Services' in the financial statement of Indian states includes, among others, education, health and family welfare, water supply, and sanitation, but excludes expenditures under anti-poverty programmes. So, to make a conformity with 'Social sector expenditure by Centre and States', that appears in Table 3, we consider Development expenditures (which combines both expenditures on Social services and expenditures on both Rural and urban Development) as one of the explanatory variables in the regression equations. Both control and choice variables considered in the regression equations affect economic growth (NSDP growth) of every state. Also important is that NSDP growth and the growth of development expenditure are converted into percentages. This is due to the fact that as the data of other variables are either in percentages or in per 1000, the regression model tries to avoid, among others, heteroskedasticity problem to minimize the widely differing values among all variables considered in the regression equations.

The regression equations reveal some important results (Table 6). First, the coefficient of multiple determination is very low $\left(R^{2}\right)$ for almost all regression equations. Second, as regards the main (choice) explanatory variables are concerned, the coefficient of Urban Gini is of expected sign (positive) for regression equations of seven out of fifteen states (Note 8) (about 47 per cent cases) although none is significant. For Rural Gini, the coefficient of Gini is of expected sign (positive) for regression equations of six out of fifteen states (Note 9) (about 40 per cent cases), where the regression coefficient of one state (Andhra Pradesh) is significant. Third, the states registering expected signs (positive) in the regression coefficients of Rural Gini and Urban Gini are different states, the exception being for Haryana but with insignificant coefficient values. Fourth, the regression results for other variables are also mixed as per the hypotheses. The regression coefficients of IMR, LEB and growth of development expenditure (in percentages) are of expected signs for most of the regression equations, though they are insignificant in almost all cases. Finally, for LIT (education variable), the regression coefficients are of expected sign (positive) for six out of fifteen states (Note 10) ( about 40 per cent cases), albeit none of them are significant.

Table 6. Effect of Rural and Urban Consumption Inequality on Economic Growth among Major Indian States

\begin{tabular}{llllllll}
\hline \multirow{2}{*}{ State } & \multirow{2}{*}{$\mathrm{R}^{2}$} & \multicolumn{7}{c}{ Coefficient } \\
\cline { 3 - 8 } & & Gini (urban) & Gini (rural) & lit & imr & leb & Growth dev ex pc \\
\hline A.P. & .224 & $-1.06(1.15)$ & $3.04^{* * *}(1.706)$ & $0.36(.633)$ & $-0.12(.27)$ & $.178(1.336)$ & $.0005(.134)$ \\
Assam & .249 & $-.439(.427)$ & $-.057(.627)$ & $-0.44(.414)$ & $-.007(.185)$ & $1.684(1.30)$ & $.002(.0371)$ \\
Bihar & .14 & $.951(2.58)$ & $-.78(2.339)$ & $1.06(.8881)$ & $.25(1.05)$ & $-1.32(2.98)$ & $.006(.118)$ \\
Gujarat & .09 & $-1.30(1.615)$ & $1.724(1.81)$ & $1.985(2.7)$ & $-.187(.593)$ & $-5.449(5.337)$ & $-0.002(.265)$ \\
Haryana & .093 & $.856(1.037)$ & $.794(11.33)$ & $-.929(2.891)$ & $-.326(.279)$ & $.870(3.002)$ & $.0009(.006)$ \\
Karnataka & .132 & $-.49(.791)$ & $-.614(1.059)$ & $-.48(1.083)$ & $-.19(.505)$ & $.53(1.815)$ & $.166(.146)$ \\
Kerala & .528 & $.379(.535)$ & $-.506(.416)$ & $.468(.722)$ & $.030(.123)$ & $.254(1.084)$ & $-.117^{* * *}(.064)$ \\
M.P. & .164 & $.488(.93)$ & $-1.08(1.01)$ & $-.76(.653)$ & $.072(.228)$ & $2.465(3.18)$ & $-.15(.175)$ \\
Maharastra & .464 & $-.41(.698)$ & $-.633(1.040)$ & $.222(.498)$ & $-.62^{* * *}(.183)$ & $-5.08^{* *}(2.158)$ & $-.086(.10)$ \\
Orissa & .167 & $-.49(.748)$ & $3.48(2.734)$ & $-3.09(2.101)$ & $-.72(.53)$ & $5.13(5.556)$ & $.107(.172)$ \\
Punjab & .224 & $.232(.384)$ & $-.016(.971)$ & $-.30(1.71)$ & $-.08(.156)$ & $-.085(6.26)$ & $.027(.028)$ \\
Rajasthan & .049 & $.531(1.96)$ & $.943(2.95)$ & $-.12(.741)$ & $-.211(.434)$ & $.213(.298)$ & $.049(.281)$ \\
T.N. & .249 & $-.72(.771)$ & $.27(.968)$ & $-.21(.748)$ & $-.45(.286)$ & $-1.42(1.74)$ & $-0.068(.108)$ \\
U.P. & .235 & .491 & -.699 & .425 & -.60 & -3.5 & .015 \\
W.B. & .244 & -.288 & .905 & -.14 & .137 & 1.05 & .03 \\
\hline Note: ${ }^{*}$ means significant in $1 \%$ level; ${ }^{* *}$ means significant in $5 \%$ level; ${ }^{* * *}$ means significant in $10 \%$ level. &
\end{tabular}


In order to examine the separate effect of both rural and urban consumption inequality on economic growth (NSDP growth in percentages) among major Indian states, we also employ separate ordinary least square regression (OLS) models mainly because of avoiding multicollinearity for both rural and urban consumption Gini in the same equation. No significant difference appears in the new regression equations (Tables $7 \& 8$ ).

Table 7. Effect of Urban Consumption Inequality on Economic Growth among Major Indian States

\begin{tabular}{lllllll}
\hline \multirow{2}{*}{ State } & \multirow{2}{*}{$\mathrm{R}^{2}$} & \multicolumn{5}{c}{ Coefficient } \\
\cline { 3 - 6 } & & Gini (urban) & lit & imr & leb & Growth dev ex pc \\
\hline A.P. & .087 & .225 & -.214 & -.178 & .26 & -.046 \\
Assam & .249 & -.455 & -.438 & -.002 & 1.71 & .002 \\
Bihar & .135 & $1.495(1.968)$ & $1.01(.849)$ & $.231(1.029)$ & $-.94(2.698)$ & $.003(.114)$ \\
Gujarat & .045 & $-1.05(1.589)$ & $.758(2.36)$ & $-.141(.59)$ & $-2.296(4.177)$ & $-.007(.264)$ \\
Haryana & .093 & $.901(.7926)$ & $-.73(.729)$ & $-.316(.237)$ & $.735(2.237)$ & $.001(.006)$ \\
Karnataka & .115 & $-.64(.731)$ & $-.16(.917)$ & $-.021(.403)$ & $.583(1.781)$ & $.188(.139)$ \\
Kerala & .489 & $-.112(.355)$ & $1.053(.545)$ & $.006(.123)$ & $-.74(.714)$ & $-.10(.069)$ \\
M.P. & .11 & $.819(.882)$ & $-.66(.648)$ & $.012(.222)$ & $1.85(3.147)$ & $-.18(.173)$ \\
Maharastra & .45 & $-.25(.635)$ & $.018(.361)$ & $-.592^{*}(.172)$ & $-4.43^{* *}(1.84)$ & $-.09(.098)$ \\
Orissa & .09 & $.19(.526)$ & $-1.17(1.49)$ & $-.44(.487)$ & $.873(4.51)$ & $.075(.173)$ \\
Punjab & .22 & $.232(.373)$ & $-.32(1.275)$ & $-.08(.124)$ & $-.008(4.21)$ & $.027(.026)$ \\
Rajasthan & .043 & $.750(1.795)$ & $-.274(.549)$ & $-.102(.263)$ & $.206(.29)$ & $.071(.266)$ \\
T.N. & .245 & $-.79(.71)$ & $-.076(.548)$ & $-.41^{* * *}(.238)$ & $-1.48(1.688)$ & $-.08(.097)$ \\
U.P. & .203 & $.308(.772)$ & $.378(.314)$ & $-.74(.435)$ & $-3.86^{* * *}(2.087)$ & $.028(.055)$ \\
W.B. & .177 & $-.714(.426)$ & $.469(.297)$ & $.109(.235)$ & $-.32(1.105)$ & $.02(.024)$ \\
\hline
\end{tabular}

Note: ${ }^{*}$ means significant in $1 \%$ level; ${ }^{* *}$ means significant in $5 \%$ level; ${ }^{* * *}$ means significant in $10 \%$ level.

Table 8. Effect of Rural Consumption Inequality on Economic Growth among Major Indian States

\begin{tabular}{|c|c|c|c|c|c|c|}
\hline \multirow{2}{*}{ State } & \multirow{2}{*}{$\mathrm{R}^{2}$} & \multicolumn{5}{|c|}{ Coefficient } \\
\hline & & Gini (rural) & lit & $\mathrm{imr}$ & leb & Growth dev ex pc \\
\hline A.P. & .187 & $2.049(1.322)$ & $-.135(.327)$ & $-.22(.246)$ & $.284(1.326)$ & $-.02(.131)$ \\
\hline Assam & .205 & $-.316(.575)$ & $-.402(.413)$ & $-.024(.185)$ & $1.19(1.209)$ & $.006(.037)$ \\
\hline Bihar & .134 & $-1.324(1.78)$ & $1.16(.825)$ & $.162(1.004)$ & $-1.905(2.47)$ & $.013(.113)$ \\
\hline Gujarat & .058 & 1.487 (1.769) & $1.672(2.647)$ & $-.116(.581)$ & $-4.50(5.159)$ & $-.0489(.256)$ \\
\hline Haryana & .059 & $6.598(8.822)$ & $-1.98(2.572)$ & $-.28(.273)$ & $1.172(2.955)$ & $.0004(.007)$ \\
\hline Karnataka & .113 & $-.83(.981)$ & $-.702(1.008)$ & $-.332(.4439)$ & $.437 \quad(1.778)$ & $.132(.134)$ \\
\hline Kerala & .515 & $-.28(.269)$ & $.702(.634)$ & $.033(.122)$ & $-.125(.93)$ & $-.124^{* * *}(.062)$ \\
\hline M.P. & .152 & $-1.25(.927)$ & $-.65(.606)$ & $.08^{*}(.222)$ & $2.48^{* *}(3.123)$ & $-.13(.168)$ \\
\hline Maharastra & .454 & $-.399(.946)$ & $.079(.428)$ & $-.58(.167)$ & $-4.56(1.934)$ & $-.08(.098)$ \\
\hline Orissa & .147 & $2.176(1.865)$ & $-2.3(1.78)$ & $-.65(.509)$ & $3.25(4.717)$ & $.098(.169)$ \\
\hline Punjab & .208 & $.015(.953)$ & $.104(1.54)$ & $-.018(.111)$ & $-.73(6.072)$ & $.035(.024)$ \\
\hline Rajasthan & .045 & $1.223(2.702)$ & $.007(.558)$ & $-.22(.42)$ & $.188(.275)$ & $.057(.272)$ \\
\hline T.N. & .212 & $.58(.91)$ & $-.402(.719)$ & $-.459(.285)$ & $-1.099(1.701)$ & $-.015(.088)$ \\
\hline U.P. & .219 & $-.57(.762)$ & $.455(.312)$ & $-.54(.451)$ & $-3.201(2.052)$ & $.021(.056)$ \\
\hline W.B. & .232 & $1.14^{* *}(.546)$ & $-.38(.343)$ & $.126(.227)$ & $1.449(1.315)$ & $.033(.024)$ \\
\hline
\end{tabular}

Note: ${ }^{*}$ means significant in $1 \%$ level; ${ }^{* *}$ means significant in $5 \%$ level; ${ }^{* * *}$ means significant in $10 \%$ level.

The differences that appear in the results are only on the nature of relationships of regression coefficients, not in the significance of regression coefficients. The coefficient of Urban Gini (Table 7) is of expected sign (positive) for regression equations of eight out of fifteen states (Note 11) (about 53 per cent cases) although none is significant, whereas in common regression equations (Table 6) the coefficient of Urban Gini is of expected sign (positive) for regression equations of seven out of fifteen states (about 47 per cent cases) none being significant. The major Indian states possessing expected signs in the regression coefficient of Urban Gini in both the models are almost the same states (Note 12). Similarly, the coefficient of Rural Gini (Table 8) is of expected sign (positive) for regression equations of eight out of fifteen states (Note 13) (about 53 per cent cases) with insignificant values for all except one state (West Bengal), whereas in common regression equations (Table 6), the regression coefficient of Rural Gini is of expected (positive) sign in six out of fifteen states (about 40 per cent cases), the 
regression coefficient being significant in one state (Andhra Pradesh), and in both the models the states are almost the same (Note 14).

These results, however, imply that that inequality of consumption expenditure induces an increase in economic growth for about 50 per cent of major Indian states (the range varies from 47 to 53 per cent cases in urban areas and 40 to 53 per cent cases in rural areas) and the regression coefficients in almost all cases are insignificant. However some improvements of these findings may be expected if the impact study could be worked out with some longer period of time rather than 25 year period used in the existing regression equations. But, more importantly, despite the fact that these regression equations do not lead to an strong indication in respect of our hypothesis in keeping with our theoretical underpinnings, this results seem to suggest that if more resources are allocated on educationprimary, secondary, above secondary and tertiary level- the effect of its externality might have the desired impact (positive and significant) on economic growth. In other words, if major share of tax-financed capital is allocated in public education, it might act as externality to everybody leading to a positive and significant impact into the growth process in all major Indian states.

That education might lead to positive externality into the growth process in spite of greater consumption inequality among population in India (or among major Indian states) is evident from sectoral composition of GDP tied with the proportion of working population engaged in different sectors in India. (Table 9)

Table 9. Occupational distribution of working population and percentage shares of different sectors in GDP

\begin{tabular}{llllllll}
\hline Sector & 51 & 61 & 71 & 81 & 91 & 00 & $07-08$ \\
\hline Primary & $72.7(59)$ & $72.3(52)$ & $72.6(44)$ & $69.3(38)$ & $67.4(33)$ & $61.3(24)$ & $55.9(19)$ \\
Secondary & $10.0(15)$ & $11.7(18)$ & $10.7(21)$ & $12.9(24)$ & $12.1(27)$ & $17.4(27)$ & $18.7(26)$ \\
Tertiary & $17.3(28)$ & $16.0(31)$ & $16.7(34)$ & $17.8(38)$ & $20.5(41)$ & $22.3(49)$ & $25.4(55)$ \\
\hline
\end{tabular}

Source: India's Economic Development Since 1947 (Ed. By Uma Kapila), Academic Publishers; http://indiabudget.nic.in; Indian Economy (Misra \& Puri), Himalaya Publishers.

The most striking feature of the structural change in the Indian economy in recent decades has been the pre-eminence of service sector, which depends completely on stepping up of educational level to the working population, as the major contributor to growth, raising its share rather sharply in the national output. The data show that the share of services has increased from about 28.5 per cent in 1950-51 to about 55 per cent in 2007-08 with the proportion of working population from about 17 per cent to about 25.4 per cent during the same period. Thus if major tax financed resources are allocated on education, such tax-financed public education might act as externality to everybody leading to a positive and significant impact into the growth process. Provided that the large proportion of working population of major Indian states get employment in the service sector.

\section{Conclusion}

In the light of our theoretical underpinnings, our central empirical issue seeks to examine whether inequality of income in major Indian states increases redistribution in favor of median voter, and thereby influencing higher economic growth. The empirics of Indian Economy lend credence to some important facts. First, the latest NSSO data suggest that median voter's consumption expenditure happens to be much below the mean for both urban and rural population in all major Indian states, and the latest data for over 30 year period reveal that consumption inequality increases in all major Indian states. Second, in spite of continuous increase in consumption inequality in major Indian states, redistribution in real social expenditure (at constant prices) by Centre and States continues to increase in real per capita terms including median voter during post-reform period indicating that the increase of inequality of income (expenditure) in major Indian states increases redistribution in favor of per capita terms including the median voter during post-reform period. Third, regarding performance of physical redistribution, literacy index is still much lower for majority of Indian states and enrolling is more difficult task than retaining the students in educational institution for those states. Also most of the major Indian states have registered poorer health performance than the rest. Finally, inequality of consumption expenditure induces an increase in economic growth for about 50 per cent of major Indian states and the regression coefficients in almost all cases are insignificant. However some improvements of these findings may be expected if the impact study could be worked out with some longer period of time rather than 25 year period used in the existing regression equations.

But the most striking feature of the structural change in the Indian economy in recent decades has been the pre-eminence of service sector, which depends completely on stepping up of educational level to the working population, as the major contributor to economic growth, raising its share rather sharply in the national output. So, although the finding of this study do not lead to an significant relationship in respect of our hypothesis, this 
results seem to suggest that, if major share of tax-financed capital is allocated in public education-primary, secondary, above secondary and tertiary level, so that it might act as externality to everybody with the provision of employment of the large proportion of working population of major Indian states in the service sector, it might lead to a positive and significant impact into the growth process in all major Indian states. To pave the way for such a public education system, special attention should be taken by the institutional source in particular not only for enrolling all the students in the educational institutions but also for retaining them in the educational institutions so that the large proportion of working population of major Indian states might get employment in the service sector.

\section{References}

Aghion, P., \& Bolton, P. (1990). A Theory of Trickle-Down Growth and Development. Review of Economic Studies, 64, 151-172. http://dx.doi.org/10.2307/2971707

Banerjee, A., \& Newman, A. (1993). Occupational choice and the process of development. Journal of Political Economy, 101, 274-298. http://dx.doi.org/10.1086/261876

Dev, M. (2008). Inclusive Growth in India: Agriculture, Poverty and Human Development. England: Oxford University Press.

Drazen, A. (2000). Political Economy in Macroeconomics. Princeton, UK: Princeton University Press.

Galor, O., \& Zeira, J. (1993). Income Distribution and Macroeconomics. Review of Economic Studies, 60, 35-52. http://dx.doi.org/10.2307/2297811

Meltzer, A., \& Richard, S. (1981). A rational theory of the size of the government. Journal of Political Economy, 89, 914-927. http://dx.doi.org/10.1086/261013

National Commission for Enterprise. (2007). The Challenge of Employment in India: An Informal Economy Perspective: Report of the National Commission for Enterprises in the Unorganized Sector. India: Academic Publisher. http://msme.gov.in/ar_2007_08_English_mainpage.pdf

NSSO $66^{\text {th }}$ Round. (July 2009-June 2010). Employment and Unemployment and Household Consumer Expenditure. www.mospi.nic.in

Persson, T., \& Tabellini, G. (1990). Macroeconomic Policy, Credibility and Politics. London: Harwood.

Persson, T., \& Tabellini, G. (1994). Is inequality harmful for growth?. American Economic Review, 84, 600-621. United States: American Economic Association.

Saint-Paul, G., \& Verdier, T. (1993). Education, Democracy and Growth. Journal of Development Economics, 42, 399-407. http://dx.doi.org/10.1016/0304-3878(93)90027-K

\section{Notes}

Note 1. For updating the poverty line for 2009-10 and beyond, Tendulkar Committee(TC) moved away from anchoring the poverty line in calorie norm as in the past based on per capita total consumer expenditure data of Uniform reference period ("last 30 days" for all items) to Modified Mixed Reference Period (involving 7-day recall period for some food items-edible oil; egg, fish \& meat; vegetables, fruits, spices, beverages and processed foods; pan, tobacco \& intoxicants-in addition to 365 day recall for low-frequency items-clothing, bedding, footwear, education, institutional medical, durable goods-and 30-day for the rest) because they argued that calorie consumption intake calculated by converting the consumed quantities in the last 30 days as collected by NSS had not been found to be well correlated either over time or across states with the nutritional outcomes observed in other specialized nutrition outcome surveys such as the National Family Health Surveys.

Note 2. There were no existence of two major Indian states (Jharkhand and Chhattisgarh) before seventh quinquennial NSSO rounds (2004-05), Those two new states, which were curved out from Bihar and Madhya Pradesh at the seventh quinquennial NSS rounds, were also covered for the first time in 2004-05 under large sample rounds of NSSO survey.

Note 3. Compound growth rate was calculated as $y=a b^{x}$, where $a$ is intercept, $b$ is regression coefficient of $y$ on $x$. $\mathrm{y}$ is the per capita real social sector expenditure (in Rs.), $\mathrm{x}$ is the year represented as $1980=1$, $1981=2 \ldots$...Compound growth rate was expressed as $\mathrm{x}=(\mathrm{Inb}-1) .100$. Significance of growth rates were tested by using ' $\mathrm{t}$ ' test with the test statistic as $\mathrm{t}=\mathrm{r} / \mathrm{SE}(\mathrm{x})$.

Note 4. In calculating Human Development Index (HDI), the UNDP (United Nations Development Programme) considers four variables: LEB ,LIT,GER and PCY at PPP. Our study considers first three variables in computing composite index. 
Note 5. For computing any individual component of index, the general formula adopted here is: Individual index $(\mathrm{II})=($ Actual value - Minimum value $) /($ Maximum value - Minimum Value $)$. But for the component Infant Mortality rate (IMR), the index was calculated as: 1-II. For combined indices, A.M. (Arithmetic Mean) was employed.

Note 6. The actual data we receive are either five or ten year intervals. So, the missing data are interpolated in all cases. In these cases the checking of stationarity seems to be not necessary. In spite of these limitations, we also checked the stationarity test in all cases. The results reveal that in almost all cases data show stationarity in the first difference forms. The rest are found stationary in the second difference forms.

Note 7. First, as regards dependent variable is concerned, we have the data of Gini coefficient of monthly per capita consumption expenditure from World Bank (2001) for the years 1977-78, 1983-84, 1986-94. The latest data available for Gini coefficient was for 2004-05 from NSSO $61^{\text {st }}$ Round (Government of India, 2011). So, to make the data of Gini coefficient continuous on and from 1981 to 2005, we make use of the procedure of interpolation. Second, the data of literacy rate (in percentage) was available from census report for the years 1981, 1991, 2001, 2011. However the procedure of interpolation is adopted to make the data of literacy rate continuous on and from 1981 to 2005. Third, the data of Infant Mortality Rate (per 1000) is available from Economic Survey, www.indiastat.com for the years 1981, 1991-2003, 2006. So, interpolation was used to make the data continuous. Fourth, interpolation is also used for Life Expectancy at Birth (per 1000 population), because Economic Survey, www.indiastat.com provides those data for the years 1980-95, 1998-2005. Fifth, both interpolation and extrapolation are used for the data regarding Gross Enrolment Rate since Economic Survey, www.indiastat.com gives the those data for the 1992-99, 2007-08. Finally, no interpolation or extrapolation was necessary for the data of the Net State Domestic Product, because Handbook of Statistics on Indian Economy publishes those data for the entire period (1981-2005).

Note 8. Major Indian States registering expected sign (positive) in the regression coefficients of Urban Gini are Bihar, Haryana, Kerala, Madhya Pradesh, Punjab, Rajasthan and Uttar Pradesh.

Note 9. Andhra Pradesh, Gujarat, Haryana, Orissa, Tamil Nadu and West Bengal are the major Indian states which have positive signs in their regression coefficients of Rural Gini.

Note 10. Major Indian States showing expected sign (positive) in the regression coefficients of LIT are Andhra Pradesh, Bihar, Gujarat, Kerala, Maharashtra and Uttar Pradesh.

Note 11. Andhra Pradesh, Bihar, Haryana, Madhya Pradesh, Orissa, Punjab, Rajasthan and Uttar Pradesh have expected (positive) sign in the regression coefficients of Urban Gini.

Note 12. The new states registering expected (positive) sign in the regression coefficient of urban Gini in Table 7 are Andhra Pradesh and Orissa instead of omission of Kerala as compared with that of Urban Gini appearing in common regression equation (Table 6).

Note 13. The states having expected sign (positive) in the regression coefficients of Rural Gini are Andhra Pradesh, Gujarat, Haryana, Orissa, Punjab, Rajasthan, Tamil Nadu and West Bengal.

Note 14. The new states registering expected (positive) sign in the regression coefficient of Rural Gini in Table 8 are Punjab, Rajasthan as compared with that of Rural Gini appearing in common regression equations (Table 6). 